\title{
Tebang, Muat dan Angkut di Wilayah PG Madukismo, Yogyakarta
}

\section{Harvest, Load, and Transport in PG Madukismo Area, Yogyakarta}

\section{Irvan Eka Kurniawan dan Purwono*}

\author{
Departemen Agronomi dan Hortikultura, Fakultas Pertanian, Institut Pertanian Bogor \\ (Bogor Agricultural University), Jalan Meranti, Kampus IPB Darmaga, Bogor 16680, Indonesia \\ Telp. \& Faks. 0251-8629353 e-mail : agronipb@indo.net.id \\ *Penulis untuk korespondensi : purwono@yahoo.com
}

Disetujui 20 Agustus 2018 / Published online 3 September 2018

\begin{abstract}
Implementation of harvesting, loading and hauling on sugarcane cultivation has an effect on low rendemen in sugar factory. Potential losses of sugar in harvest and transport activities start from the time of logging, loading, transport to the factory, until the cane queue before milling. The observation is held at Madukismo Sugar Factory on 5 February 2017 until 5 June 2017. The quality of harvest, load and haul in Bantul and Sleman is not significantly different except the yield of sugar. The quality of harvest practices can be assessed from several criteria: the decrease of the brix from the field to the factory, the loss of sugarcane yield, and the efficiency of the harvest worker. This is because the characteristics and general conditions of the garden are not much different. The quality of harvest, load and haul in both areas is not significantly different due to the characteristic and general condition of the field which is not much different. Harvest, load and transport are appropriate and efficient reflected by the principles of MBS (Sweet, Clean and Fresh). Implementation of MBS principle can prevent the decrease of rendemen at the time of harvesting, loading and transportation of sugarcane.
\end{abstract}

Keywords: harvest, sugarcane, yield

\begin{abstract}
ABSTRAK
Pelaksanaan tebang, muat dan angkut pada budidaya tebu memiliki pengaruh terhadap rendahnya rendemen di pabrik gula. Potensi kehilangan gula pada proses tebang angkut dimulai dari saat penebangan, pemuatan, pengangkutan ke pabrik, hingga antrian tebu menjelang digiling. Kegiatan pengamatan dilaksanakan di Pabrik Gula Madukismo pada tanggal 5 Februari 2017 hingga 5 Juni 2017. Kualitas pelaksanaan tebang, muat dan angkut di Wilayah Bantul dan Sleman tidak berbeda nyata kecuali pada rendemen sementara. Kualitas pelaksanaan tebang dapat dinilai dari beberapa kriteria yaitu besar penurunan brix dari kebun ke pabrik, kehilangan hasil tebu, serta efisiensi tenaga tebang. Kualitas pelaksanaan tebang, muat dan angkut pada kedua wilayah tidak berbeda nyata karena karakterisitik dan kondisi umum kebun yang tidak berbeda jauh. Tebang, muat dan angkut yang tepat dan efisien dicerminkan oleh prinsip MBS (Manis, Bersih dan Segar). Penerapan prinsip MBS dapat mencegah penurunan rendemen pada saat kegiatan tebang, muat dan angkut tebu.
\end{abstract}

Kata kunci : panen, tebu, rendemen 


\section{PENDAHULUAN}

Perkembangan produksi tebu di Indonesia selama lima tahun terakhir cukup fluktuatif. Tahun 2011 produksi tebu (setara gula) mencapai 2,24 juta ton dan naik pada tahun 2012 menjadi 2,60 juta ton. Sedangkan pada tahun 2013 produksi tebu (setara gula) kembali meningkat menjadi 2,55 juta ton, begitu juga pada tahun 2014 mengalami kenaikan sebesar 0,86 persen menjadi 2,58 juta ton. Sementara tahun 2015 produksi tebu mengalami penurunan sebesar 1,57 persen menjadi 2,53 juta ton (BPS, 2016). Penyebab fluktuatifnya produksi tebu adalah terjadinya penurunan produksi pada tahun-tahun tertentu sehingga diperlukan upaya peningkatan produktivitas. Salah satu upaya untuk meningkatkan produktivitas gula ialah menerapkan sistem budidaya tanaman tebu yang baik dan benar.

Menurut Amalia (2012), sistem budidaya tanaman tebu yang baik dan benar memperhatikan segala aspek mulai dari pemilihan varietas yang unggul, pemeliharaan tanaman tebu yang intensif hingga prosedur penebangan yang sesuai jadwal. Kegiatan teknik budidaya tanaman tebu yang sangat berpengaruh terhadap nilai kualitas dan kuantitas tebu salah satunya adalah pada saat tebang angkut. Beberapa faktor pada aspek tebang muat dan angkut yang mempengaruhi produktivitas yaitu, tinggi rendahnya rendemen tebu asli dari kebun, kebersihan tebangan saat tebu ditebang (kualitas tebang) dan jangka waktu antara tebu di tebang hingga tebu digiling (Darmohardjo, 2014).

Menurut Haryanti (2008), kebersihan tebu hasil pemanenan sangat berperan penting terhadap nilai rendemen. Semakin besar persentase trash yang terdapat pada tebu yang akan digiling maka rendemen yang dihasilkan akan menurun. Selain itu, permasalahan yang terjadi pada proses tebang muat dan angkut yaitu setelah tebu ditebang kandungan sukrosa yang terdapat dalam batang tebu akan mengalami degradasi yang dapat menyebabkan kegagalan dalam membentuk gula kristal. Selain itu, proses penundaan giling dapat menyebabkan susutnya bobot tebu dan meningkatnya kadar gula reduksi. Tujuan penelitian adalah mengamati dan membandingkan pelaksanaan tebang, muat dan angkut di wilayah Bantul dan Sleman serta menganalisis proses tebang, muat, dan angkut yang tepat, optimal dan efisien terhadap rendemen tebu.

\section{METODE}

Kegiatan pengamatan dan pengumpulan data dilaksanakan di wilayah PG Madukismo PT Madubaru, Desa Tirtonimolo, Kasihan, Bantul, Yogyakarta selama empat bulan mulai dari 5 Febuari sampai dengan 5 Juni 2017.

\section{Pengamatan, Pengumpulan Data dan Informasi}

Pengamatan dilakukan pada dua wilayah kebun tebu rakyat, setiap wilayah diambil lima kebun sebagai ulangan. Penentuan batang contoh pada tebu lahan kering dilakukan dengan memilih tiga juring dan ditentukan spot contoh sepanjang 15 meter pada bagian tengah (Gambar 1). Penentuan batang contoh dilakukan dengan memilih tiga batang pada juring contoh 1, empat batang pada juring contoh 2 dan tiga batang pada juring nomor 3 sehingga total sepuluh tanaman contoh per kebun.

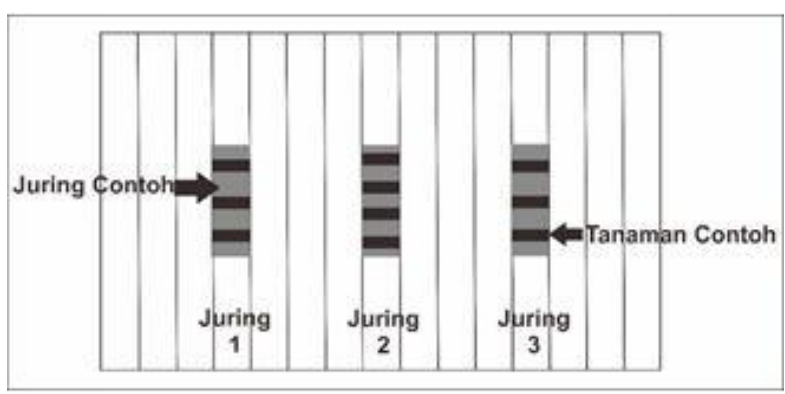

Gambar 1. Layout pengamatan pada kebun tebu sistem mekanisasi

\section{Pengumpulan Data Primer}

Data primer didapat dari hasil pengamatan langsung yaitu;

\section{Brix di Kebun}

Pengukuran brix dilakukan dengan cara menebang batang tebu contoh lalu diperas bagian tengah ruas dan dikeluarkan niranya pada 3 titik yaitu bagian atas, tengah, dan bawah batang. Angka yang terbaca saat peneropongan dengan handrefractometer merupakan nilai brix nira tebu saat di kebun.

\section{Kehilangan Hasil Tebu}

Kehilangan hasil tersebut dapat dihitung dengan memotong tunggak atau bagian batang tebu tidak tertebang yang tingginya lebih dari $5 \mathrm{~cm}$, mengumpulkan lonjoran dan pucuk (potensi menjadi gula) lalu ditimbang bobotnya. Data bobot lima juring contoh dirata-ratakan. Bobot kehilangan hasil yang diperoleh dari lima juring contoh dikonversikan ke hektar dengan menggunakan rumus; 
Kehilangan hasil setiap $\mathrm{Ha}=\frac{\text { Bobot } 3 \text { juring }(\mathrm{Kg})}{3} \times$ Faktor juring

Faktor juring = Jumlah juring/luas netto kebun

\section{Taksasi Maret}

Perhitungan taksasi memerlukan data pengamatan dari komponen hasil diantaranya;
a) Jumlah juring.ha ${ }^{-1}$
b) Panjang juring efektif (panjang juring yang terdapat batang tebu)
c) Jumlah batang per meter juring
d) Panjang batang (titik patah sampai ujungnya)
e) Bobot per meter batang

Taksasi produksi dapat dihitung dengan rumus; Taksasi $=$ Faktor juring $\mathrm{x}$ Jumlah batang/m juring $\mathrm{x}$ Panjang batang $\mathrm{x}$ bobot/m batang

\section{Prestasi Kerja}

Prestasi kerja tenaga tebang dilakukan dengan menghitung jumlah tenaga tebang dan bobot tebu yang dapat ditebang setiap harinya. Prestasi kerja dapat dihitung dengan menggunakan rumus;

$$
\frac{\begin{array}{l}
\text { Prestasi Kerja } \\
\text { Bobot tebu }
\end{array}}{\text { Jumlah tenaga tebang } \times \text { Standar kerja }}
$$

\section{Brix dan Pol di Pabrik}

Pengukuran brix dan pol di pabrik dilakukan dengan menggiling batang contoh yang diambil pada saat di kebun sejumlah sepuluh batang per kebun di gilingan contoh. Selanjutnya nira yang keluar diukur nilai brix nya dengan menggunakan serta persen pol dengan menggunakan polarimeter. Angka yang didapatkan dari pembacaan polarimeter dimasukkan ke dalam rumus;

$$
\% \text { Pol }=\frac{\text { Pemutaran } \times \text { Bobot normal } \times 1.1}{\text { Berat jenis } \times 100}
$$

Setelah mendapatkan nilai pol, hasil dari pembacaan brix dan pol berguna untuk mendapatkan nilai rendemen sementara dengan menggunakan rumus;

Nilai nira $\quad=P o l-(0.4 \times($ brix $-P o l))$

Rendemen Sementara $=$ Faktor rendemen $x$ nilai nira

\section{Analisis Data}

Data dan informasi yang diperoleh selama magang dianalisis menggunakan perhitungan matematika sederhana seperti nilai rata-rata dan persentase. Data primer dianalisis dengan menggunakan uji $t$-student $5 \%$ dengan bantuan program minitab untuk membandingkan proses tebang, muat dan angkut pada dua wilayah tebu rakyat. Data yang telah diolah selanjutnya diambil kesimpulannya. Data sekunder dan hasil wawancara dianalisis secara deskriptif.

\section{HASIL DAN PEMBAHASAN}

Pelaksanaan tebang, muat dan angkut tebu di PG Madukismo diawali dengan melaksanakan analisis pendahuluan untuk menilai faktor kemasakan, koefisien daya tahan dan koefisien peningkatan, hasil analisis pendahuluan dijadikan dasar untuk menentukan jadwal tebang. Selain melalui analisis pendahuluan, penentuan jadwal tebang juga dibuat berdasarkan scoring yang dilakukan oleh Bina Sarana Tani terhadap kebun-kebun tebu giling. Poin-poin yang menentukan scoring diantaranya masa tanam, varietas, serangan hama, dan kondisi khusus (banjir). Langkah selanjutnya dalam perencaan pelaksanaan tebang yaitu pelaksanaan taksasi Maret. Taksasi Maret yaitu melakukan pengamatan untuk menghitung perkiraan produktivitas kebun tebu giling. Hasil taksasi Maret ini digunakan untuk menentukan keperluan tenaga tebang, truk angkut, dan komponen lain penunjang pelaksanaan tebang angkut spesifik di wilayah tertentu.

Pelaksanaan tebang, muat dan angkut dimulai dengan penerbitan SPA (Surat Perintah Angkut), penerbitan dilakukan untuk memudahkan administrasi pembagian jatah angkut masing-masing mandor. Tebang dan angkut dapat dilakukan apabila mandor tebang sudah diberikan SPA. Setelah tebu diangkut ke pabrik, truk angkut yang mengangkut tebu dari kebun diperiksa dibeberapa pos pengecekan untuk mengetahu bobot bersih dan besar rafaksi, kemudian tebu dibongkar dari truk ke lori dan menunggu hingga digiling.

Pelaksanaan tebang, muat dan angkut di PG Madukismo diawasi berdasarkan prinsip MBS (Manis, Bersih, Segar). Tebu yang akan menjadi bahan baku untuk giling merupakan tebu yang masak, yaitu tebu yang berumur 12 bulan dan memilik brix dan pol tinggi. Selain itu tebu yang akan menjadi bahan baku harus bersih dari segala jenis kotoran (akar, daun kering, pucuk, bahan non tebu) karena kotoran tersebut dapat menurunkan rendemen karena tidak mengandung gula. Bahan baku tebu yang akan digiling merupakan tebu yang segar atau tebu yang mengantri tidak lebih dari 48 jam setelah ditebang di kebun. Penerapan MBS tersebut dapat mengurangi potensi kehilangan gula saat pelaksanaan tebang, muat, dan angkut tebu.

\section{Pengukuran Brix dan Pol}

Nilai brix dan pol merupakan komponen yang digunakan untuk menentukan rendemen sementara. Pengukuran nilai brix dilakukan saat 
tebu ditebang di kebun dan saat tebu di pabrik, sedangkan pengukuran pol hanya dilakukan di pabrik. Tabel 1 merupakan data hasil pengamatan brix di kebun serta brix dan pol di pabrik kebun wilayah Bantul dan Sleman. Hasil dari kedua data di bawah dianalisis dengan menggunakan uji $t$ student pada taraf $\alpha=5 \%$ untuk membandingkan pengukuran nilai brix, pol dan rendemen sementara di kedua wilayah.

Tabel 1. Hasil pengukuran brix dan pol di kebun wilayah Bantul dan Sleman

\begin{tabular}{|c|c|c|c|c|c|c|}
\hline Kebun & $\begin{array}{c}\text { Brix } \\
\text { lapangan }\end{array}$ & $\begin{array}{c}\text { Brix } \\
\text { pabrik }\end{array}$ & $\begin{array}{c}\text { Penurunan } \\
\text { Brix }\end{array}$ & $\% \mathrm{Pol}$ & Nilai nira & $\begin{array}{l}\text { Rendemen } \\
\text { Sementara }\end{array}$ \\
\hline \multicolumn{7}{|c|}{ Bantul } \\
\hline Dadapan & 14,70 & 14,25 & 0,45 & 12,35 & 11,59 & 7,07 \\
\hline Glondong & 16,50 & 15,55 & 0,95 & 12,53 & 11,32 & 6,91 \\
\hline Wonokromo & 16,00 & 15,65 & 0,35 & 11,90 & 10,40 & 6,34 \\
\hline Pacar & 18,70 & 17,35 & 1,35 & 11,93 & 9,76 & 5,95 \\
\hline Kulon Pandeyan & 21,10 & 20,65 & 0,45 & 16,69 & 15,09 & 9,21 \\
\hline Rata-rata & 17,40 & 16,69 & 0,71 & 13,08 & 11,63 & 7,10 \\
\hline \multicolumn{7}{|c|}{ Sentul } \\
\hline Brintikan & 19,00 & 17,75 & 1,25 & 16,68 & 15,09 & 8,56 \\
\hline Sambirejo & 18,50 & 17,35 & 1,15 & 14,63 & 13,54 & 8,26 \\
\hline Sikarang & 17,70 & 16,12 & 1,58 & 13,98 & 13,12 & 8,01 \\
\hline Sunten & 18,10 & 17,95 & 0,15 & 15,18 & 14,07 & 8,58 \\
\hline Tegal Ombo & 18,90 & 18,85 & 0,05 & 14,68 & 13,01 & 7,94 \\
\hline Rata-rata & 18,44 & 17,60 & 0,84 & 15,03 & 13,77 & 8,27 \\
\hline $\mathrm{P}$-value & & & $0,738^{\mathrm{tn}}$ & $0,092^{\text {tn }}$ & & $0,078^{\mathrm{tn}}$ \\
\hline
\end{tabular}

Rendemen tebu adalah kadar kandungan gula di dalam batang tebu yang dinyatakan dengan persen. Bila dikatakan rendemen tebu 10 $\%$, artinya ialah bahwa dari $100 \mathrm{~kg}$ tebu yang digiling di Pabrik Gula akan diperoleh gula sebanyak $10 \mathrm{~kg}$. Rendemen sangat dipengaruhi oleh kualitas nira. Kualitas nira dapat diukur dari kadar brix, persen pol dan nilai nira tebu. Brix merupakan satuan yang menyatakan persen zat padat kering terlarut dalam larutan $(\mathrm{g} / 100 \mathrm{~g}$ larutan) yang dihitung sebagai gula sedangkan pol merupakan jumlah sukrosa (g) yang terlarut dalam 100 gram larutan (Kuspratmo dan Fakhry, 2012). Semakin tinggi brix dan pol dari nira tebu maka menunjukan tingginya kadar gula dari nira tebu. Oleh karena itu analisis brix dan pol menjadi dasar untuk menghitung jumlah gula yang dihasilkan (rendemen) sebuah pabrik gula.

Berdasarkan hasil pengamatan pada Tabel 1, kadar brix nira pada tebu di kebun Bantul dan Sleman mengalami penurunan setelah sampai di pabrik. Penurunan kadar brix tersebut disebabkan oleh reaksi invertasi terhadap molekul sukrosa. Reaksi invertasi merupakan reaksi hidrolisis irreversible dimana satu molekul sukrosa dan satu molekul air menghasilkan satu molekul glukosa dan satu molekul fruktosa (Filianty, 2007). Reaksi invertasi menyebabkan kandungan gula reduksi (glukosa, fruktosa) dalam nira meningkat dan menurunkan kadar brix. Faktor yang dapat mempengaruhi reaksi invertasi yaitu suhu, $\mathrm{pH}$, aktivitas enzim invertase, dan mikroorganisme.
Reaksi invertasi dapat melalui katalisis biokimia dengan beberapa enzim, khususnya invertase (Wang, 2004). Enzim invertase terdapat dalam tanaman tebu dan juga dapat dihasilkan oleh beberapa mikroorganisme jenis khamir Saccharomyces cerevisiae atau Saccharomyces carisbergensis (Filianty, 2007). Enzim invertase pada tanaman tebu digunakan untuk menguraikan sukrosa menjadi glukosa saat proses respirasi. Reaksi invertasi dipercepat dengan suhu tinggi dan optimal pada suhu $55 \mathrm{C}$ (Prasetyo et al, 2016). Proses dari penebangan, muat hingga angkut ke pabrik memerlukan waktu yang cukup lama. Hal tersebut menyebabkan tebu terpapar cahaya matahari dan terkena suhu yang tinggi sehingga reaksi invertasi berlangsung lebih cepat. Setelah sampai pabrik tebu kembali terpapar cahaya matahari karena adanya antrian di pos tebu masuk dan antrian lori menjelang digiling.

Mikroorganisme juga dapat menghasilkan enzim dextransucrase yang dapat mengkonversi sukrosa menjadi dextran dan fruktosa. Dextran dapat menghambat proses kristalisasi gula karena merupakan senyawa yang tidak dikehendaki. Mikroorganisme dapat mengingeksi tebu ketika proses tebang muat dan angkut melalui bekas tebangan pada batang dimana kondisi lingkungan yang tidak steril dari mikroorganisme. Keberadaan mikroorganisme juga dapat menyebabkan proses fermentasi pada nira tebu sehingga $\mathrm{pH}$ menjadi asam dan mempercepat 
reaksi invertasi dimana optimal pada $\mathrm{pH} 4,5$ (Chaplin, 2004).

Analisis data yang dilakukan pada variabel penurunan brix, pol dan rendemen sementara dari kedua wilayah menunjukan hasil yang tidak berbeda nyata. Hal tersebut dapat dilihat dari nilai P-value ketiga variabel yang masih diatas 0,05 meskipun dari rata-rata menunjukan penurunan brix, pol dan rendemen sementara wilayah Sleman lebih besar dari wilayah Bantul. Akan tetapi untuk peubah rendemen sementara pada wilayah Sleman dapat dikatakan lebih besar dibandingkan wilayah bantul. Hal tersebut disebabkan selisih rendemen meskipun sebesar satu sangat sensitif dan berpengaruh besar terhadap perhitungan produksi gula. Hasil yang tidak berbeda nyata pada peubah brix da pol disebabkan kondisi kebun yang diamati di wilayah Bantul dan Sleman tidak berbeda jauh. Kondisi tebu di kedua wilayah banyak yang roboh, tidak diklentek kedua, dan terdapat banyak gulma sehingga akar, daun kering dan gulma ikut terangkut pada saat pengangkutan. Kotoran yang ikut terangkut pada saat pengangkutan banyak mengandung mikrooganisme yang dapat menyebabkan penurunan kandungan gula hingga $50 \%$ dalam proses invertase gula menurut (Kulkarni dan Warne, 2004).

\section{Taksasi Maret dan Kehilangan Hasil}

Taksasi pada tanaman tebu umunya dilakukan sebanyak dua kali yaitu taksasi Desember dan taksasi Maret. Taksasi dilaksanakan untuk memperkirakan produktivitas suatu kebun tebu giling. Data taksasi kemudian digunakan untuk mempersiapkan rencana tebang dan angkut. Tabel 2 merupakan hasil taksasi Maret dan pengamatan kehilangan hasil di kebun tebu giling wilayah Bantul dan Sleman.

Tabel 2. Produktivitas dan kehilangan hasil tebu wilayah Bantul dan Sleman

\begin{tabular}{|c|c|c|c|c|c|c|}
\hline \multirow{2}{*}{ Kebun } & \multirow{2}{*}{ Luas (ha) } & \multirow{2}{*}{$\begin{array}{l}\text { Produktivitas Taksasi } \\
\text { Maret (ton ha-1) }\end{array}$} & \multicolumn{4}{|c|}{ Standar Kehilangan Hasil } \\
\hline & & & $\%$ & ton.ha-1 & $\%$ & ton.ha-1 \\
\hline \multicolumn{7}{|c|}{ Bantul } \\
\hline Dadapan & 1,62 & 109,1 & 5 & 5,46 & 6,41 & 6,99 \\
\hline Glondong & 1,31 & 98 & 5 & 4,9 & 7,29 & 7,14 \\
\hline Wonokromo & 2,48 & 68,5 & 5 & 3,43 & 11,81 & 8,09 \\
\hline Pacar & 3,34 & 105 & 5 & 5,25 & 4,37 & 4,79 \\
\hline Kulon Pandeyan & 1,25 & 80 & 5 & 4 & 8,81 & 8,37 \\
\hline Rata-rata & 2 & 92,12 & & 4,61 & & 7,08 \\
\hline \multicolumn{7}{|c|}{ Sleman } \\
\hline Brintikan & 3,80 & 65,00 & 5,00 & 3,25 & 2,26 & 1,63 \\
\hline Sambirejo & 1,40 & 55,00 & 5,00 & 2,75 & 14,62 & 8,13 \\
\hline Sikarang & 2,32 & 66,30 & 5,00 & 3,32 & 9,14 & 6,66 \\
\hline Sunten & 0,97 & 73,70 & 5,00 & 3,69 & 2,36 & 1,89 \\
\hline Tegal Ombo & 1,26 & 61,20 & 5,00 & 3,06 & 2,83 & 1,86 \\
\hline Rata-rata & 1,95 & 64,24 & & 3,21 & & 4,03 \\
\hline $\mathrm{P}$-value & & $0,01^{*}$ & & & & $0,082^{\text {tn }}$ \\
\hline
\end{tabular}

Pengamatan kehilangan hasil dilakukan dengan menjumlahkan tiga bentuk kehilangan pada tebu diantaranya kehilangan hasil tunggak, pucuk dan lonjoran. Standar kehilangan hasil PG Madukismo yaitu maksimal sebesar $5 \%$ dari produktivitas kebun.

Berdasarkan hasil analisis data taksasi Maret pada Tabel 2, produktivitas di wilayah Bantul lebih besar dari wilayah Sleman. Hal tersebut disebabkan kerapatan tanaman per juring di kebun di wilayah Bantul cukup banyak serta bobot tebu yang besar meskipun banyak juga tebu yang roboh, sedangkan kebun di wilayah Sleman unggul pada tinggi tebu akan tetapi kerapatannya kurang dan bobotnya tidak sebesar tebu di wilayah Bantul.
Kehilangan hasil tebu dapat mengurangi persentase hablur gula yang dihasilkan, hal tersebut disebabkan pucuk, lonjoran, dan tunggak yang tertinggal memiliki potensi untuk menjadi gula akan tetapi tidak ikut diangkut ke pabrik untuk digiling. Kehilangan hasil tunggak disebabkan penebangan yang kurang mepet tanah atau penebangan batang tebu yang menyisakan lebih dari $5 \mathrm{~cm}$ pangkal batang. Kehilangan hasil dari lonjoran disebabkan kondisi tebu yang roboh sehingga ada beberapa batang yang terlewat oleh para penebang, sedangkan kehilangan hasil dari pucuk disebabkan penebang menyisakan lebih dari dua ruas dari pucuk.

Berdasarkan Tabel 2, standar kehilangan hasil di PG Madukismo maksimal sebesar 5\%. 
Akan tetapi rata-rata kehilangan hasil yang diamati di kebun melebihi standar maksimal yang ditetapkan. Salah satu penyebab tingginya kehilangan hasil adalah kurangnya sosialisasi SOP tebang yang baik dan benar kepada tenaga tebang. Berdasarkan pengamatan di lapangan beberapa tenaga tebang belum semua paham mengenai SOP penebangan tebu yang baik dan benar. Selain itu, kondisi tebu di kebun yang roboh dan belum di klentek kedua menyebabkan penebang kesulitan dalam melakukan penebangan.

Berdarkan hasil analisis data kehilangan hasil tebu pada Tabel 2, kehilangan hasil tebu di wilayahBantul tidak berbeda nyata dengan wilayah Sleman meskipun dari rata-rata lebih besar pada wilayah Bantul. Hal tersebut disebabkan kondisi kebun yang tidak berbeda jauh, tebu di kebun banyak yang roboh, belum diklentek kedua, dan sosialisasi dan kontrol SOP oleh mandor tebang yang dinilai masih kurang di kedua wilayah.

\section{Efisiensi Tenaga Tebang}

Salah satu aspek perencanaan dalam tebang, muat dan angkut tebu yaitu menentukan jumlah tenaga tebang yang dibutuhkan di suatu kebun. PG Madukismo mendatangkan tenaga tebang dari berbagai daerah diluar wilayah kerja seperti Wonosobo, Sragen, Batang, Brebes dan Cirebon. Setiap kemandoran diberikan target tebu masuk setiap harinya, untuk itu diperlukan penentuan kebutuhan tenaga penebang sebelum melakukan kegiatan tebang, muat dan angkut. Tabel 3 merupakan hasil pengamatan mengenai tenaga tebang di wilayah Bantul dan Sleman.

Tabel 3. Prestasi tenaga tebang di kebun wilayah Bantul dan Sleman

\begin{tabular}{|c|c|c|c|c|c|c|}
\hline Kebun & $\begin{array}{l}\text { Produksi } \\
\text { (ton) }\end{array}$ & $\begin{array}{l}\text { Jumlah } \\
\text { Tenaga } \\
\text { Tebang }\end{array}$ & PK & $\begin{array}{c}\text { Standar } \\
\text { (ton.hari-1) }\end{array}$ & $\begin{array}{c}\text { Angkut } \\
\text { (ton.hari-1) }\end{array}$ & $\begin{array}{c}\text { Selesai } \\
\text { Pengangkutan } \\
\text { (hari.ha-1) }\end{array}$ \\
\hline \multicolumn{7}{|c|}{ Bantul } \\
\hline Dadapan & 176,74 & 16,00 & 1,56 & 1,20 & 30,00 & 6,00 \\
\hline Glondong & 128,38 & 29,00 & 1,16 & 1,20 & 40,20 & 3,00 \\
\hline Wonokromo & 169,88 & 15,00 & 0,83 & 1,20 & 15,00 & 11,00 \\
\hline Pacar & 350,70 & 7,00 & 1,19 & 1,20 & 10,00 & 35,00 \\
\hline Kulon Pandeyan & 100,00 & 9,00 & 0,93 & 1,20 & 10,00 & 10,00 \\
\hline Rata-rata & 185,14 & 15,20 & 1,13 & 1,20 & 21,04 & 13,00 \\
\hline \multicolumn{7}{|c|}{ Sleman } \\
\hline Brintikan & 247,00 & 4,00 & 1,04 & 1,20 & 5,00 & 29,00 \\
\hline Sambirejo & 77,00 & 5,00 & 0,92 & 1,20 & 5,50 & 14,00 \\
\hline Sikarang & 153,82 & 3,00 & 1,39 & 1,20 & 5,00 & 31,00 \\
\hline Sunten & 71,49 & 14,00 & 0,98 & 1,20 & 16,50 & 4,00 \\
\hline Tegal Ombo & 77,11 & 22,00 & 1,04 & 1,20 & 27,50 & 3,00 \\
\hline Rata-rata & 125,28 & 9,60 & 1,07 & 1,20 & 11,90 & 20,00 \\
\hline
\end{tabular}

Keterangan : P-value yang tercantum merupakan hasil pengujian pada taraf $\alpha=5 \%$

Setiap mandor diberikan target tebu masuk per hari agar kebutuhan bahan baku giling tetap terpenuhi. Oleh karena itu tiap mandor perlu menentukan berapa jumlah tenaga tebang yang diperlukan. Berdasarkan standar PG Madukismo, setiap penebang minimal mendapatkan 1,2 ton tebu per harinya. Kegiatan penebangan menggunakan sistem borongan, setiap kuintal tebu dihargai Rp. $4.500-6.000$ dalam kondisi kebun normal. Harga per kuintal tebu dapat melonjak naik apabila kondisi kebun mengharuskan penebang mengangkut lebih jauh untuk memuat ke truk.

Kendala yang diamati saat penebangan adalah banyaknya tenaga yang pulang, sehingga jumlah tenaga yang ada tidak dapat memenuhi target tebu masuk per hari sehingga realisasi tebang dibawah perencanaan. Keterbatasan tenaga penebang tersebut membuat SPA per hari menjadi sedikit dan penyelesaian tebang di kebun menjadi lebih lama.

Berdasarkan analisis data prestasi kerja penebang pada Tabel 3, prestasi tenaga tebang di kebun wilayah Bantul dan Sleman tidak berbeda nyata. Hal tersebut disebabkan pencapaian penebang kedua wilayah mendekati standar kerja perusahaan. Hasil menunjukan tidak ada perbedaan meskipun terdapat selisih prestasi kerja sebesar 0,06 antara wilayah Bantul dan Sleman, hal tersebut ditunjukan oleh nilai P-value sebesar 0,701 (diatas 0,05 ). 
Tabel 4. Pebadingan biaya pokok dan kapasitas kerja sistem panen tebu di PG Jatitujuh dan PG Madukismo

\begin{tabular}{lcc}
\hline \multicolumn{1}{c}{ Sistem Panen } & Kapasitas Tebang (ton.hari-1) & Kebutuhan Tenaga Tebang (orang.ha-1) \\
\hline Manual & 1,20 & 50 \\
Semi mekanis & 2,50 & 24 \\
\hline
\end{tabular}

Keterangan : Kebutuhan tenaga tebang per hektar di asumsikan produktivitas 60 ton.ha ${ }^{-1}$

Berdasarkan Tabel 4, kapasitas tebang sistem panen semi mekanis lebih besar dibanding manual. Hal tersebut disebabkan perbedaan sistem pemuatan tebu ke atas truk. Pemuatan pada sistem panen semi mekanis menggunakan mesin grab loader sedangkan tenaga tebang hanya melakukan penebangan saja, sehingga tebu yang dipanen lebih banyak. Kebutuhan tenaga tebang sistem manual per hektar apabila produktivitas diasumsikan sebesar 60 tonha $^{-1}$ berjumlah dua kali lipat dari kebutuhan tenaga tebang dengan sistem semi mekanis. Hal tersebut sesuai dengan pernyatan James (2004), bahwa bahwa aplikasi mekanisasi pada kegiatan pemuatan dapat mengurangi kebutuhan tenaga kerja hingga 50\% apabila dibandingkan dengan muat manual.

Sistem panen paling efisien adalah sistem semi mekanis karena memiliki kapasitas kerja lebih tinggi sehingga tebu yang dihasilkan lebih banyak dengan tenaga kerja yang sedikit. Penggunaan mekanisasi ini juga dapat menanggulangi permasalahan kelangkaan tenaga kerja yang terjadi di perkebunan tebu. Akan tetapi penerapan sistem panen semi mekanis dapat diterapkan pada kebun dengan syarat luasan minimal 10 ha. Sistem tersebut masih belum efisien jika diterapkan pada PG Madukismo saat ini terutama di wilayah Bantul dan Sleman, karena kebun di PG Madukismo mayoritas adalah kebun milik petani dengan luasan $1-5$ ha.kebun $^{-}$ 1. Sehingga sistem panen yang efisien dan diterapkan oleh PG Madukismo saat ini adalah sistem panen manual.

\section{KESIMPULAN}

Kualitas kegiatan tebang, muat dan angkut di wilayah Bantul dan Sleman tidak berbeda nyata kecuali peubah rendemen sementara pada wilayah Sleman lebih besar dibanding wilayah Bantul. Kualitas tersebut ditunjukan oleh brix, pol, kehilangan hasil, dan prestasi kerja penebang yang tidak berbeda nyata. Hal tersebut disebabkan kondisi umum kebun di kedua wilayah yang hampir sama. Kondisi kebun yang sama diantaranya, tebu banyak yang roboh, tebu yang tidak diklentek kedua, serta banyaknya gulma menyebabkan kualitas tebangan di kedua wilayah tidak berbeda. Oleh karena itu, pelaksanaan tebang, muat dan angkut oleh PG
Madukismo di wilayah Bantul dan Sleman belum optimal.

Tebang, muat dan angkut yang tepat dan efisien dicerminkan oleh prinsip MBS (Manis, Bersih dan Segar). Tebu yang masuk ke pabrik harus tebu yang sudah matang atau memiliki brix dan pol yang tinggi serta bersih dari semua jenis kotoran (akar, pucuk, daun kering). Kebersihan tebu dari kotoran tergantung keterampilan tenaga tebang dan penerapan SOP tebangan di lapangan. Selain itu tebu yang digiling harus segar, tebu segar adalah tebu yang digiling tidak lebih dari 48 jam. Penundaan giling dapat berpengaruh pada penurunan kadar brix dan pol sehingga rendemen tidak maksimal. Penerapan prinsip MBS dapat mencegah penurunan rendemen pada saat kegiatan tebang, muat dan angkut tebu.

\section{DAFTAR PUSTAKA}

Amalia, D.R. 2012. Pengelolaan Tanaman Tebu (Saccharum officinarum L.) di PG Madukismo PT Madubaru Yogyakarta dengan Aspek Khusus Manajemen Tebang Angkut Tebu. Skripsi. Institut Pertanian Bogor. Bogor.

[BPS] Badan Pusat Statistik. 2016. Perkembangan Produksi Tebu 2015. [Internet] [diunduh pada 2016 Oktober 18] tersedia pada: https://www.bps.go.id/index.php/publikasi/4261.

Chaplin, M. 2004. Sucrose. di dalam Columbia Encyclopedia, Sixth Edition 2006.

Filianty, F. 2007. Teknik penghambatan degradasi sukrosa dalam nira tebu (Saccharum officinarum) menggunakan akar kawao (Millettia sericea) dan kulit batang manggis (Garcinia mangostana L.). Tesis. Institut Pertanian Bogor. Bogor

Haryanti, V. 2008. Analisa Sistem Pemanenan Tebu (Saccharum officinarum L.) yang Optimal di PG Jati Tujuh, Majalengka, Jawa Barat. Skripsi. Institut Pertanian Bogor. Bogor. 
Kulkarni, V.M., D. Warne. 2004. Reduction of sugar loss due to 'cut-to-mill'delay by the application of a unique new chemical composition called sucroguard. Proc S Afr Sug Technol Ass. pp. 78-90.

Prasetyo, P., W.H. Susanto, S.D. Wijayanti. 2016. Pengaruh kondisi penyimpanan tebu pragiling dan pemberian konsentrasi antiinversi terhadap kualitas nira dan rendemen sementara. J Pangan dan Agroindustri 4(1):137-147.
Sitinjak, M.T.M. 2014. Pengelolaan Tanaman Tebu (Saccharum officinarum L.) di Pabrik Gula Madukismo dengan Aspek Khusus Manajemen Tebang. Skripsi. Institut Pertanian Bogor. Bogor.

Wang, N.S. 2004. Enzyme Kinetics of Invertase Via Initial Rate Determination. Department of Chemical Engineering. University of Maryland.

Weekes, D. 2004. Sugarcane. 2nd ed. James G, editor. Blackwell Publishing, Oxford. 